RAFAŁ KOCHANOWICZ

Instytut Filologii Polskiej

Uniwersytet im. Adama Mickiewicza w Poznaniu
Images

vol. XXIX/no. 38

Poznań 2021

ISSN 1731-45OX

\title{
Temporalne aspekty gier cyfrowych
}

\begin{abstract}
AвstraCt. Kochanowicz Rafał, Temporalne aspekty gier cyfrowych [Temporal aspects of digital games]. "Images" vol. XXIX, no. 38. Poznań 2021. Adam Mickiewicz University Press. Pp. 95-111. ISSN 1731-450X. DOI 10.14746/i.2021.38.06.

Temporal issues related to digital games go beyond the strictly literary or film studies character of the description and implies technological and marketing issues. It can be outlined by referring to the concept of Andrzej Stoff, who analyzed the spatial dimension of the world of the novel ("delineating space", "creating", "functionalizing", "valorising"). Relating these four detailed issues - constituting the basic subject of description, analysis and interpretation - to temporal aspects, it is appropriate to talk about measuring (conventionalizing, relativizing) time, thematizing, functionalizing and valorizing it. Taking into account the above categories, the most typical concretizations of temporal phenomena can be further defined: functional (classic chronometry, clock, server time, time of a running process), gameplay (real time, relativization, quest time, respawn time), thematic concretizations (e.g. retrospection as a compositional dominant of multimodal narratives) and marketing concretizations (commercialization of time).
\end{abstract}

KEYWORDS: digital games, multimodal narratives, time, gameplay, thematization, commercialization

Problematyka temporalna w odniesieniu do gier komputerowych jest dość skomplikowana. Czas - jako zjawisko - wykracza poza obszar cyfrowych rzeczywistości i determinuje każdy aspekt realnej egzystencji[1]. Pozostaje równocześnie jednym z podstawowych elementów wirtualnej rozgrywki i tym samym określa niekiedy warunek sine qua non zwycięskiego jej ukończenia. Pod tym względem można go $\mathrm{w}$ cyfrowych produkcjach postrzegać podobnie jak w grach tradycyjnych i sportowych, w których temporalna wymierność działań uczestników wyznacza przebieg wypadków i dodatkowy ich aspekt związany z tak zwaną walką z czasem czy „grą na czas”. O ile w grach tradycyjnych i sportowych czas jest przede wszystkim swoistym determinantem, o tyle w grach cyfrowych pełni znacznie więcej funkcji, co z kolei poniekąd wymusza interdyscyplinarny charakter analizy. Akcentują to między innymi Jose P. Zagal i Michael Mateas w artykule Time in Video Games: A Survey and Analysis: „Głębokie zrozumienie czasowości w grach wideo wymaga przyjęcia wielu jednoczesnych perspektyw, w tym czysto strukturalnych, a także kognitywnych i związanych ze społeczno-kulturowymi aspektami czasu" [2].

[1] Złożoność problematyki czasu znakomicie odsłania książka Rüdigera Safrański Safrańskiego Czas. Co czyni z nami i co my czynimy z niego, przeł. B. Baran, Warszawa 2017.

[2] "A deep understanding of temporality in video games requires multiple simultaneous perspectives, in- cluding the purely structural as well as cognitive and sociocultural aspects of time"; M. Mateas, J. Zagal, Time in Video Games: A Survey and Analysis, <https:// www.researchgate.net/publication/247740288_Time_ in_Video_Games_A_Survey_and_Analysis>,dostęp: 10.12.2020. 
Wielofunkcyjność czasu w grach cyfrowych określa zresztą nie tylko sam wirtualny kontekst przygody, ale także mechanika rozgrywki i skorelowana z nią złożoność cyfrowej opowieści. Analiza temporalnych aspektów w omawianych grach wiąże w tej perspektywie - co oczywiste - ciężar refleksji z kwestiami, które wyznacza analiza przestrzeni. Dotyczy to szczególnie struktury ujętych w grze zdarzeń czy w szerszym ujęciu - narracyjnych cech cyfrowych historii będących multimodalną kompilacją narracji tradycyjnej - zarówno literackiej, jak i filmowej. Na narracyjne mechanizmy kreowania czasu opowieści zwracają uwagę między innymi Huaxin Wei, Jim Bizzocchi, Tom Calvert w artykule Time and Space in Digital Game Storytelling, stwierdzając przy tym fakt, że nawet zapożyczone elementy z poetyki literatury czy filmu nie pozbawiają gier unikalnej specyfiki: „Gry dziedziczą projekty niektórych temporalnych konwencji ze starszych mediów, takich jak film. Jednak ze względu na ludyczną dynamikę gameplaya, wzmocnioną mocą obliczeniową, czas w grach cyfrowych ma również unikalne cechy, które ułatwiają lub pośredniczą zarówno w rozgrywce, jak i związanej z nią narracji” [3].

Problematyka temporalna związana z grami cyfrowymi wykracza także poza stricte literaturoznawczy czy filmoznawczy charakter opisu z tego powodu, że implikuje dodatkowo kwestie technologiczne i marketingowe. Można ją wszakże - nie komplikując zbytnio sprawy spróbować zarysować, odwołując się do koncepcji Andrzeja Stoffa, który analizował przestrzenny wymiar świata powieściowego[4]. Wyszczególnione przez wspomnianego badacza cztery kwestie szczegółowe, stanowiące podstawowy przedmiot opisu, analizy i interpretacji (wykorzystane już do analizy przestrzeni w grach cyfrowych), należałoby jednak w odniesieniu do aspektów temporalnych zmodyfikować[5]. W najprostszym ujęciu można je rozpisać jak ukazano na il. 1.

Uwzględniając powyższe kategorie, wypada w dalszej kolejności określić najbardziej typowe konkretyzacje zjawisk temporalnych, decydujące zarówno o samym charakterze rozgrywki, mechanice, tematyce współtworzonej opowieści, jak i o kwestiach marketingowych, będących coraz częściej jednym z elementów wirtualnej przygody. Zestawienie wspomnianych konkretyzacji może wyglądać jak ukazano na il. 2.

[3] „Games do inherit certain temporal design conventions from oldermedia like film. However, due to the dynamic nature of ludic gameplay, augmented by the power of computation, time in digital games also has unique characteristics that facilitate or mediate both the gameplay and the associated narrative"; H. Wei, J. Bizzocchi, T. Calvert, Time and Space in Digital Game Storytelling <https://www.hindawi.com/ journals/ijcgt/2010/897217/>, dostęp: 10.12.2020.
[4] Por. A. Stoff, Studia z teorii literatury i poetyki historycznej, Lublin 1997, s. 152.

[5] Por. R. Kochanowicz, Fabularyzowane gry komputerowe w przestrzeni humanistycznej. Analizy, interpretacje i wnioski z pogranicza poetyki, aksjologii, dydaktyki literatury, Poznań 2014, s. 96-101. 
Kategorie opisu

przestrzeni w powieści

/grach (inspiracja - A.

Stoff)

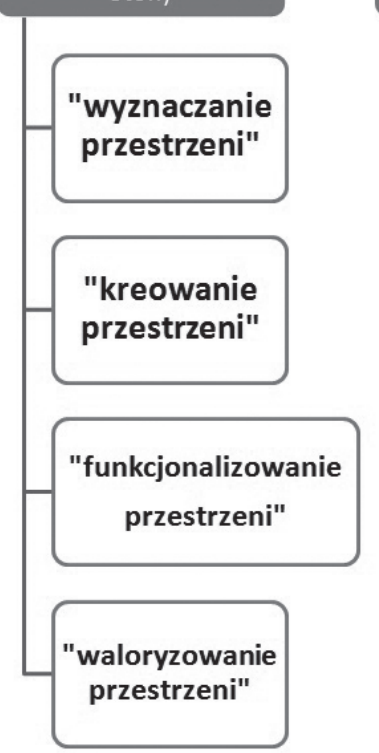

Kategorie opisu czasu w

grach cyfrowych

odmierzanie/konwencjonalizowanie /relatywizowanie

czasu

tematyzowanie

czasu

funkcjonalizowanie

czasu

waloryzowanie

czasu
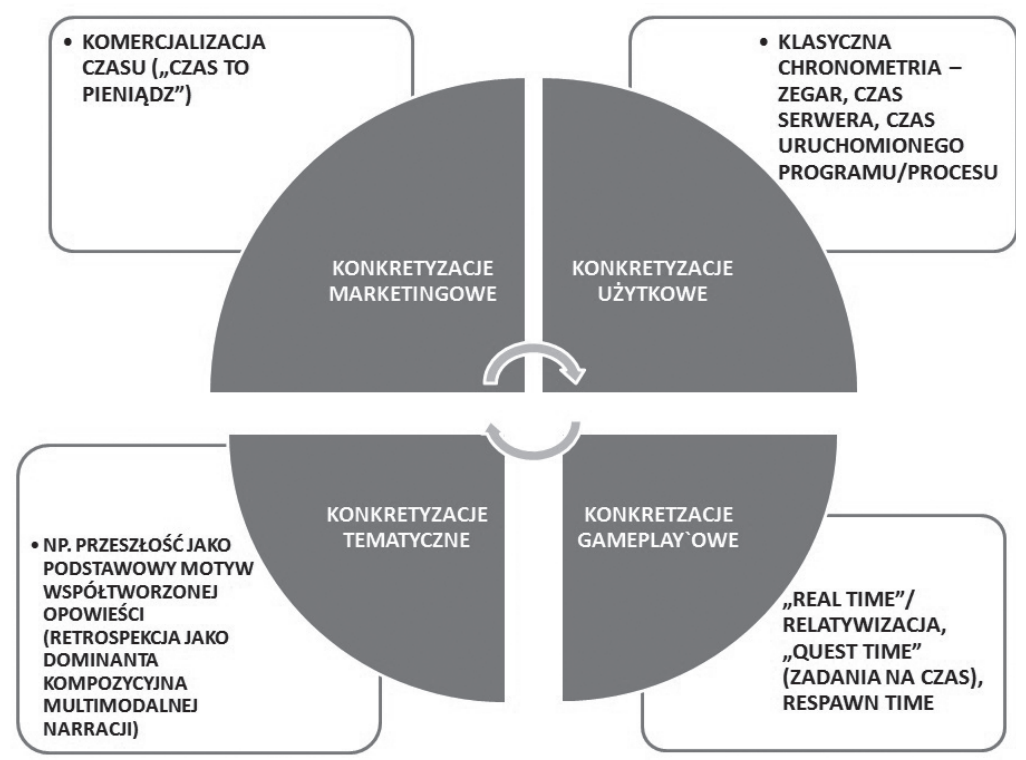

Należy jednak w tym miejscu wyraźnie zaznaczyć, że tak wyszczególnione konkretyzacje zjawisk temporalnych bardzo często współwystępują i wzajemnie się uzupełniają w poszczególnych tytułach. I jest to oczywiście związane z multimodalnym charakterem omawianych tu tekstów kultury. 
Konkretyzacje użytkowe
O tym, jak istotną funkcję pełni czas w grach cyfrowych, świadczy już choćby fakt, że niektóre ich odmiany zyskały swoje nazwy właśnie w związku z temporalnymi uwarunkowaniami rozgrywki. Wymownym przykładem pozostają tak zwane strategie czasu rzeczywistego (RTS real time strategy) czy FPS-y (first person shooter), będące w większości wypadków de facto "taktykami czasu rzeczywistego". W tych przypadkach sytuacja jest z pozoru dość oczywista - gracze rywalizują z sobą czy z komputerem, wykonując określone działania w czasie rzeczywistym. Równocześnie jednak aspektem determinującym efektywność owych działań, w ramach rozgrywki sieciowej, jest technologiczny aspekt czasu. Jakość internetowego połączenia (związana z tak zwanym pingiem, lagami etc.), decydująca o opóźnieniach $\mathrm{w}$ transmisji danych, wpływa zasadniczo zarówno na sam przebieg, jak i końcowy efekt gry. W potyczkach amatorów nie ma to daleko idących konsekwencji, ale w przypadku rozgrywek e-sportowych może decydować o karierze poszczególnych zawodników. Na portalach związanych z e-sportem nie brakuje poradników i sugerowanych rozwiązań problemu. W jednym z nich - Jak zmniejszyć ping w CS:GO? - czytamy na przykład:

Od momentu rozpowszechnienia gier internetowych, społeczność zmaga się z problemem zbyt dużego pingu. Czas upływa, a ludzie nadal narzekają na obciążenia internetowe. Jak sobie z tym radzić w CS:GO? Co możemy zrobić, by ustabilizować nasz ping? Przeczytaj poniższy poradnik, a się dowiesz.

Czym jest ping w CS:GO?

Mówiąc najprościej, ping to opóźnienie sygnału. Innymi słowy czas, jaki potrzebny jest na przesłanie informacje z naszego komputera do serwera CS:GO. Następnie przetrawienie tej informacji przez serwer i odesłanie informacji ponownie do naszego komputera. Na wzrost pingu ma wpływ multum czynników, ale głównym determinującym natężenie jest lokalizacja serwera gry. Im bliżej was jest serwer, tym mniejszy ping będziecie mieli. Przyjęło się, że najlepszy ping do gry w CS:GO to 10-30 ms. Wówczas tak naprawdę nie odczuwamy opóźnienia i gra się najwygodniej.

Jak zmniejszyć ping w CS:GO?

1) Restart routera

Najprostszym i często niedocenianym rozwiązaniem jest po prostu restart routera. Po odłączeniu routera od prądu, odczekajcie chwilę (nawet do 5 minut). Jeżeli problem ustanie, ale będzie się często powtarzał, trzeba rozważyć kupno nowego routera. Jeżeli po restarcie ping się nie poprawi, trzeba rozważyć kolejny krok[6].

Powyższy opis - chciałoby się powiedzieć - „kłopotów graczy z czasem" dotyczy jednego z najpopularniejszych FPS-ów - kolejnej odsłony Counter Strike’a i oprócz instrukcji demaskuje też iluzoryczny wymiar rozgrywki w „czasie rzeczywistym”. Dla graczy upływa on tak samo, ale uwarunkowania technologiczne relatywizują go w wymiarze audiowizualnym, co sprawia, że choć działania użytkowników mają wspólny i ten sam moment, to gameplayowe konkretyzacje owych
[6] Por. Jak zmniejszyć ping w CS:GO?, <https:// esportmania.pl/counter-strike-global-offensive/csgo- -jak-zmniejszyc-ping-instrukcja-poradnik-counter-

-strike/snw5fhy>, dostęp: 10.12.2020. 
zabiegów - wszystko, co gracze słyszą i widzą na ekranie - mają swoje własne i zróżnicowane momenty czasowe.

Typowymi użytkowymi konkretyzacjami czasu w grach pozostają jednak najróżniejsze chronometry, które odmierzają na przykład:

- rzeczywisty upływ czasu zgodnie z daną strefą czasową (czas rzeczywisty oraz tak zwany server time, czyli pomiar czasu rzeczywistego wyświetlany na danym serwerze);

- czas uruchomionego w grze procesu (na przykład tak zwany cooldown) czy programu (czas spędzony w grze).

Powyższe - użytkowe - pomiary nie budzą większych wątpliwości, natomiast gameplayowe konkretyzacje czasu są już kwestią znacznie bardziej złożoną i zróżnicowaną, mają one bowiem charakter konwencjonalny i z reguły pozostają jednym z elementów światotwórczych[7]. Pomiar skonwencjonalizowanego czasu, kalendarz, zmiany dobowe etc., z którymi styka się gracz, stanowią zwykle po prostu dodatkowy mechanizm sankcjonujący fantastyczny wymiar ukazanego świata - mającego konkurencyjną topografię, wierzenia, zegar i kalendarz. Widać to szczególnie wyraźnie w produkcjach nastawionych na światocentryczny sposób prezentowania wydarzeń, w których twórcy położyli nacisk na eksploracyjny i rozwojowy charakter prowadzenia rozgrywki. Zaliczają się do nich przede wszystkim popularne i rozbudowane gry fabularyzowane, oferujące odbiorcy bardziej lub mniej „otwarty” świat (tak zwany open world), stanowiący zwykle adaptację funkcjonującego już w kulturze uniwersum (na przykład Star Trek, Star Wars itp.) lub świadectwo oryginalnych pomysłów programistów (na przykład Tamriel, świat Fallouta itp.). Wypada też w tym miejscu zaznaczyć różnicę związaną z grami MMO, gdzie czas świata gry upływa niezależnie od działań gracza (nie może gry zapisać, cofnąć etc.) i jest wspólny dla wszystkich zalogowanych użytkowników, a produkcjami dla pojedynczego odbiorcy, w których są już znacznie większe możliwości manipulowania skonwencjonalizowanym porządkiem temporalnym (można zapisywać i cofać poszczególne etapy rozgrywki). W obu przypadkach gameplayowe konkretyzacje czasu pozostają jednak świadectwem zabiegów światotwórczych i równocześnie w istotnym stopniu determinują - a czasem komplikują - przebieg wirtualnej przygody.

Przykładem złożoności gameplayowej konkretyzacji czasu pozostaje choćby Lord of the Rings Online (Turbine, 2007+), gra MMO, w której twórcy rozwijają literackie pomysły Tolkiena. Stopień skomplikowania temporalnych relatywizacji gameplaya odsłania już w tym przypadku równie skomplikowany opis tak zwanego Time of day gry na fanowskich stronach:

In the Lord of the Rings Online 24 hours of "game time" (a game-day) takes 3 hours and 6 minutes of "real time" (wall-clock time).

[7] Obszernie problematykę światotwórstwa rozważa Krzysztof M. Maj w książce: Światotwórstwo w fanta-

\section{Konkretyzacje} gameplayowe 
The time of day is divided into 10 blocks of time.

These time periods can be seen on your "Radar," by mousing over the sun or moon icon.

The icon will show the sun during the day-time and the moon during the night-time.

The icon changes to a clock in the 11 oclock position when you're in certain kinds of Instances, since it can take place at any time of day. For example, the Helm's Deep Epic Battles take place Before Midnight, After Midnight, Before Dawn, and Sunrise.

Day-time runs from "dawn" to "dusk," while night-time runs from the "gloaming" to "foredawn."

Note that the periods, "dawn," "gloaming," and "midnight," are much shorter than the other time periods.

Time of day may change after maintenance or an update to the game. This is especially noticeable if one of your lua plugins has a clock that tells you when the next in-game time «segment» starts.

Day-Time lasts 1 hour 42 minutes 20 seconds

- Dawn $=9$ minutes 32 seconds

- Morning $=28$ minutes 42 seconds

- Noon $=17$ minutes 47 seconds

- Afternoon $=27$ minutes 58 seconds

- Dusk $=18$ minutes 21 seconds

Night-Time lasts 1 hour 23 minutes 40 seconds

- Gloaming $=9$ minutes 30 seconds

- Evening = 27 minutes 59 seconds

- Midnight $=8$ minutes 59 seconds

- Late Watches $=19$ minutes 1 second

- Foredawn $=18$ minutes 11 seconds $[8]$.

Jest to produkcja MMO, więc wydarzenia w świecie gry toczą się własnym rytmem, niezależnie od tego, czy gracz jest zalogowany, czy nie. Równocześnie niektóre questy można wykonać jedynie

[8] „We Władcy Pierścieni Online 24 godziny «czasu gry» (dzień gry) zajmują 3 godziny i 6 minut «czasu rzeczywistego» (zegar ścienny). Pora dnia jest podzielona na 10 bloków czasu. Te okresy można zobaczyć na swoim «radarze», najeżdżając kursorem myszy na ikonę słońca lub księżyca. Ikona będzie pokazywać słońce w ciągu dnia i księżyc w nocy. Ikona zmienia się w zegar na pozycji godziny 11, gdy jesteś w niektórych rodzajach Instancji, ponieważ może to mieć miejsce o dowolnej porze dnia. Na przykład, bitwy epickie w Helm's Deep Epic mają miejsce przed północą, po północy, przed świtem i wschodem słońca. Dzień trwa od «świtu» do «zmierzchu», a noc od «zmroku» do «przedświtu». Zwróć uwagę, że pory «świt», «zmrok» i «północ» są znacznie krótsze niż pozostałe okresy. Pora dnia może ulec zmianie po konserwacji lub aktualizacji gry. Jest to szczególnie zauważalne, jeśli jedna z twoich wtyczek lua ma zegar, który mówi ci, kiedy rozpocznie się następny «segment» czasu w grze.

Czas dzienny trwa 1 godzinę 42 minuty 20 sekund

- Świt $=9$ minut 32 sekundy

- Ranek = 28 minut 42 sekundy

- Południe $=17$ minut i 47 sekund

- Popołudnie $=27$ minut 58 sekund

- Zmierzch $=18$ minut 21 sekund

Noc trwa 1 godzinę 23 minuty 40 sekund

- $\mathrm{Zmrok}=9$ minut 30 sekund

- Wieczór $=27$ minut 59 sekund

- Północ = 8 minut 59 sekund

- Late Watches $=19$ minut 1 sekunda

- Przedświt $=18$ minut 11 sekund"”'

Time of day, <https://lotro-wiki.com/index.php/

Time_of_day>, dostęp: 10.12.2020. 
w określonych ramach czasowych, podobnie jak zmierzyć się z wybranymi przeciwnikami, którzy cyklicznie pojawiają się w danej lokacji wyłącznie o ustalonych porach (respawn time), co w pewnym stopniu ogranicza swobodę rozgrywki. Twórcy wszakże, projektując konkretyzację konkurencyjnego i zrelatywizowanego porządku temporalnego, próbowali spotęgować - chciałoby się powiedzieć: co do sekundy immersyjne wrażenie „zamieszkiwania” wirtualnego, tolkienowskiego uniwersum[9]. I nie jest to bynajmniej przypadek odosobniony. Podobne gameplayowe konkretyzacje czasu znajdujemy też w grach z Uniwersum-X, na przykład X2: The Threat (Egosoft, 2004). Konwencja rozbudowanego kosmicznego symulatora, przenoszącego gracza do odległych zakątków kosmosu uzasadnia w gameplayu światotwórczą, temporalną relatywizację. Sprawia ona graczom trochę problemów, o czym można się przekonać śledząc dyskusję na forach:

\section{How long is a Mizura?}

Anyone know how long is a Mizura is? One minute or one hour....

Re: How long is a Mizura?

1 Second is NOT 1 Sezura!!!

It's always $1, \mathrm{xx}$ to $\mathrm{xxx} . .$. we have to find the right converting. I found something:

Sezura $=$ is the smallest unit; is about $1.7 \mathrm{~s}$

Mizura $=96$ Sezura $=163.2 \mathrm{~s}=2.72 \mathrm{~m}$

Stazura $=96$ Mizura $=15667.2 \mathrm{~s}=261.12 \mathrm{~m} 4.352 \mathrm{~h}$

Tazura $=7$ Stazuras $=109670.4 \mathrm{~s}=1827.84 \mathrm{~m} 30.464 \mathrm{~h} 1.27 \mathrm{t}$

Wozura $=7$ tazuras $=8.89 \mathrm{t}$

Mazura $=7$ Wozuras $=62.23 \mathrm{t}$

Jazura $=8$ Mazuras $=56$ Wozuras $=392$ tazuras $=497.84 \mathrm{t}=1.36 \mathrm{j}$

And some only in the teladian empire exist some:

Quazura $=22$ Mizuras $=3590.4 \mathrm{~s}=59.84 \mathrm{~m}$ (looks like an human hour).

Inzura $=8$ Mizuras $=1305.6 \mathrm{~s}=21.76 \mathrm{~m}$

Sun $=1$ Jazura $[10]$

Wykonywanie questów w sfunkcjonalizowanym gameplayowo czasie - w ciągu „mizur” czy „stazur” - nie tylko konwencjonalizuje

[9] Problematykę „Zamieszkiwania wirtualnych światów" bardzo interesująco omawia Michał Kłosiński w książce Hermeneutyka gier wideo. Interpretacja, immersja, utopia, Warszawa 2018.

[10] „Jak długa jest Mizura?

Czy ktoś wie, jak długa jest Mizura? Minuta lub godzina...

\section{Re: Jak długa jest Mizura?}

1 sekunda to NIE 1 Sezura!!!

Zawsze jest 1 , xx do xxx .... musimy znaleźć odpowiednią konwersję. Znalazłem coś:

Sezura = to najmniejsza jednostka; wynosi około 1,7 s

Mizura $=96$ Sezur $=163,2 \mathrm{~s}=2,72 \mathrm{~m}$

Stazura $=96$ Mizur $=15667,2 \mathrm{~s}=261,12 \mathrm{~m} \mathrm{4,352}$ godz

Tazura $=7$ Stazur $=109670,4 \mathrm{~s}=1827,84 \mathrm{~m} \mathrm{30,464} \mathrm{h}$

$1,27 \mathrm{t}$
Wozura $=7$ tazur $=8,89 \mathrm{t}$

Mazura $=7$ Wozur $=62,23 \mathrm{t}$

Jazura $=8$ Mazur $=56$ Wozur $=392$ tazur $=497,84$ $\mathrm{t}=1,36 \mathrm{j}$

A niektóre istnieją tylko w imperium teladiańskim, niektóre:

Quazura $=22$ Mizur $=3590,4$ s = 59,84 $\mathrm{m}$ (wygląda jak ludzka godzina).

Inzura $=8$ mizur $=1305,6 \mathrm{~s}=21,76 \mathrm{~m}$

Sun $=1$ Jazura". How Long is a Mizura?, <http://forum.egosoft.com/viewtopic.php?t=272328>, dostęp: 10.12.2020. 
sposób prowadzenia rozgrywki, ale poniekąd wymusza naukę nowej „temporalnej nawigacji” i może - zapewne wbrew intencji twórców przynajmniej na początku przygody, być elementem, który Piotr Kubiński nazywa emersyjnym[11]. Ponadto - jeśli podjęte w rozgrywce zadanie musi być wykonane w określonym i najczęściej krótkim czasie, a takich w tej produkcji nie brakuje - on sam zyskuje nacechowanie negatywne, jest bowiem nie tylko determinantem, ale także przeciwnikiem, jego upływ staje się przeszkodą, trzeba z nim po prostu wygrać.

Mniej skomplikowane - ale również światotwórcze - konkretyzacje czasu proponuje w swoich produkcjach Bethesda Softworks. W serii The Elder Scrolls - ukazującej otwarty, fantastyczny świat Tamriel - twórcy zmodyfikowali zarówno kalendarz, wprowadzając własne nazewnictwo i konstelacje[12], jak i zrelatywizowali czas w gameplayu - 1 minuta czasu rzeczywistego odpowiada upływowi 20 minut w świecie gry. Czas płynie jeszcze szybciej w Fallout 4. Tym razem programiści z Bethesdy zrelatywizowali go w skali: 1 sekunda czasu rzeczywistego równa się 1 minuta w świecie gry.

Powyższy tytuł, podobnie, jak i Skyrim, to produkcje przeznaczone dla pojedynczego gracza, który gameplayowym czasem może manipulować znacznie bardziej, niż na przykład w LOTRO i w ten sposób funkcjonalizować go dla potrzeb wybranego sposobu rozgrywki. Poczynając od wspomnianego już zapisywania i cofania jej etapów, a na przyspieszaniu upływu skonwencjonalizowanego czasu kończąc:

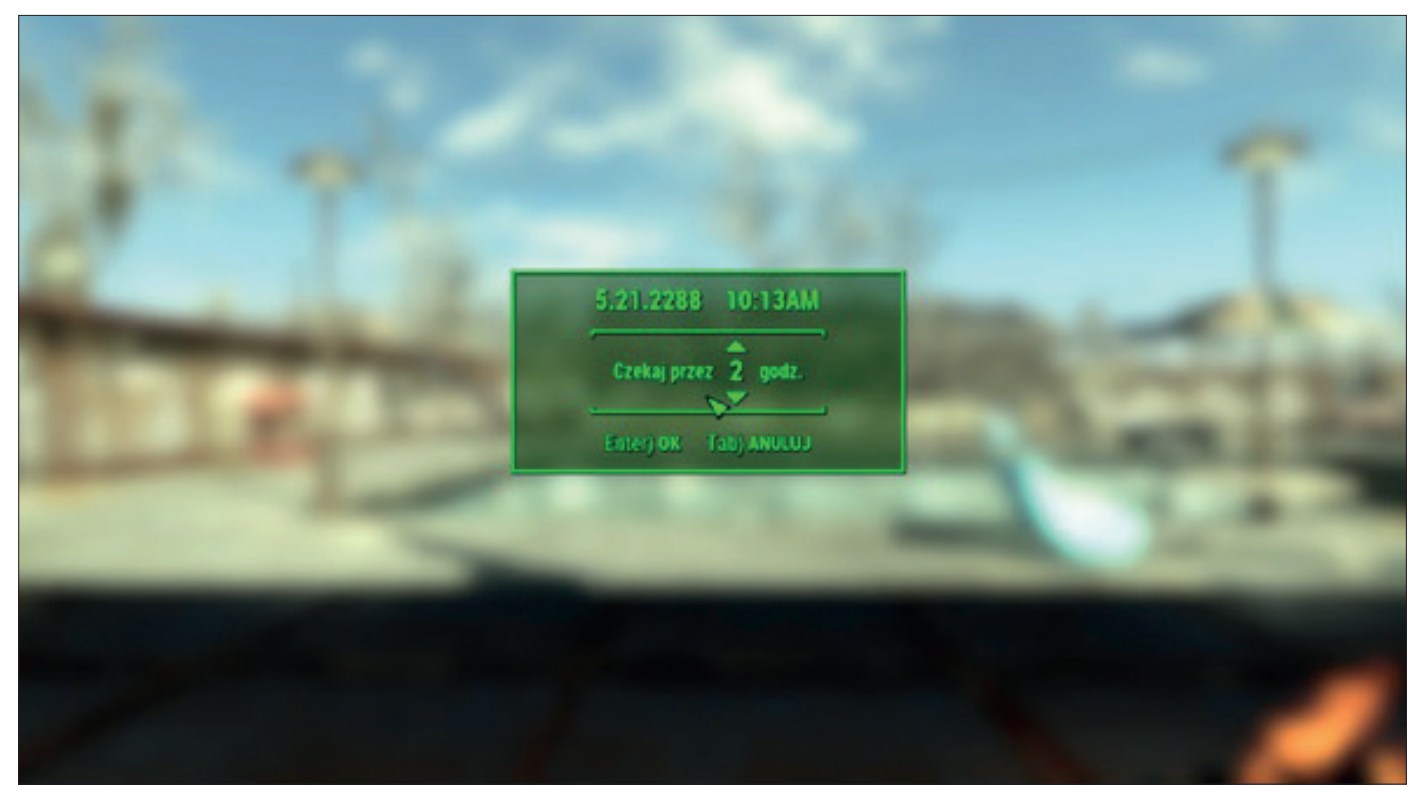

Il. 3. Zrzut ekranu z gry Fallout 4, Bethesda Softworks, 2015. Źródło: opracowanie własne
[11] Por. P. Kubiński, Gry wideo. Zarys poetyki, Kraków 2016.
[12] Por. Lore:Calendar, <https:// en.uesp.net/wiki/Lore:Calendar>, dostęp: 10.12.2020. 
Gra - jako komputerowy program - umożliwia też metagamingowe ingerowanie w zaprojektowane opcje temporalne, na przykład wpisywanie programistycznych komend modyfikujących opracowane przez twórców ustawienia.

Przywołane przykłady pozostają jednymi z wielu, pokazują światotwórczy aspekt sfunkcjonalizowanych, gameplayowych konkretyzacji czasu, jego konwencjonalizację i relatywizację. Tę ostatnią można zresztą odnotować najczęściej, jest bowiem także świadectwem programistycznych konieczności. Podróż w grze nie może trwać tak samo długo jak w rzeczywistości (gra mogłaby stać się nudna), szczególnie że sukcesywnie rozrastają się cyfrowe (najczęściej fantastyczne) przestrzenie, w efekcie czego gameplayowa opcja tak zwanej szybkiej podróży stała się w wielu najnowszych produkcjach nieodzownym elementem.

Interesującym wyjątkiem pod tym względem pozostaje dość szczególna, sięgająca korzeniami 8- i 32-bitowych komputerów seria kosmicznych symulatorów - Elite. Pomysłodawcą i reżyserem jest David Braben, a jego koncepcja, w miarę wiernego odzwierciedlenia Drogi Mlecznej (w skali $1: 1$ ), znalazła swoje apogeum w ostatniej części Elite Dangerous (Frontier Developments, 2014, gra MMO). Generowane proceduralnie miliardy ciał niebieskich gracze mogą eksplorować w czasie rzeczywistym, korzystając jedynie $\mathrm{z}$ fantastycznych napędów (na przykład supercruise, hyperspace etc.), które co prawda skracają czas podróży, ale w skali całej dostępnej galaktyki i kosmicznych odległości nie jest to usprawnienie bardzo znaczące Jak bowiem możemy przeczytać w oficjalnych, związanych z grą statystykach - odkrycie całości zajmie około 36338 rzeczywistych lat, a do tej pory społeczność graczy poznała mniej, niż 1\% wirtualnej Drogi Mlecznej:

Statystki

64214901 zapisane układy.

62256725 ze znanymi współrzędnymi.

8574087 z zablokowanymi współrzędnymi.

283510504 zachowanych ciał niebieskich

2777 udostępniona trasa.

183943821 wpisy w 79000 dziennikach lotów

26717 wpisy w 5619 dziennikach pokładowych

0,016049\% galaktyki zostało odkryte w EDSM. Odkrycie całości zajmie 36388 lat, 4 miesiące, 11 dni.

Aktualna znana populacja galaktyki: 6633479668483

Aktualny stan towarów w giełdzie galaktycznej: 107662200386 t[13]

Ten - chciałoby się powiedzieć - kosmiczny ogrom ma też swoje temporalne konsekwencje. Osobliwą przygodę jednego z niefortunnych graczy odnotowały m.in. światowe, związane z grami serwisy:

An Elite Dangerous pilot has been stuck in space for three months

Fuel Rats to the rescue, again.

[13] Por. EDSM: Elite Dangerous Star Map, <https:// www.edsm.net/pl>, dostęp: 10.12.2020. 
An Elite Dangerous pilot, Commander Deluvian Reyes Cruz, has been stranded in space for three months. Ambitiously hoping to set a record for the furthest distance travelled from Sol, he has instead found himself trapped in the lifeless abyss beyond the edge of the Milky Way, no doubt risking space madness. It took him over a month to reach that point, and he's been stuck there since November. This week, rescue is finally in sight. [...] [By Fraser Brown February 18, 2019, PC Gamer][14]

„Operacja ratunkowa”, w którą zaangażowała się spora część społeczności, była niemal globalnym przedsięwzięciem i kolosalnym wyzwaniem logistycznym. Elite Dangerous jest wszakże wyjątkiem, a sposób prezentowania kosmicznej przestrzeni uzasadnia w tej produkcji właśnie taką temporalną konwencję.

Konkretyzacje tematyczne
Czas - głównie miniony - bywa w grach cyfrowych, szczególnie tych najbardziej rozbudowanych i fabularyzowanych, coraz częściej tematem i jako taki determinuje poetykę multimodalnych narracji. Innymi słowy podróże do przeszłości, wspomnienia, pamiętniki, dzienniki czy dawne epoki to motywy, które określają nie tylko światotwórczy wymiar cyfrowej rzeczywistości, ale także wpływają na sposób prezentacji ujętej w grze opowieści. We wszystkich przywołanych wcześniej tytułach, do których można by zresztą doliczyć większość najnowszych produkcji (na przykład Wiedźmina 3: Dziki Gon z dodatkami: Serce z kamienia i Krew i wino, gry z serii Assassin's Creed - Origins i Odyssey, produkcje BioWare: Star Wars The Old Republic, Mass Effect: Andromeda czy Star Trek Online i wiele innych) przeszłość i związane z nią - w ten czy inny sposób konkretyzowane - retrospekcje są jednym $z$ podstawowych elementów multimodalnych narracji[15]. Obejmują niemal wszystkie aspekty współtworzenia ujętej w grze opowieści. Poczynając od struktury questów (na przykład wprowadzenie do zadania ma często charakter retrospektywny), poprzez narrację środowiskową (na przykład odkrywanie ukrytych w scenerii detali z przeszłości), rozwój prowadzonego bohatera (jego wspomnienia), aż do różnorodnie konkretyzowanych podróży w czasie (na przykład retrospektywne „cutscenki” czy „flashbacki” etc.) (il. 4).

Ta swoista popularność motywu przeszłości i jego retrospektywny, choć zróżnicowany sposób prezentacji wynika - z jednej strony - z dążenia twórców do światotwórczej komplementarności,
[14] „Pilot Elite Dangerous utknął w kosmosie na trzy miesiące.

Znowu „szczury paliwowe” wyruszają na ratunek. Elite Dangerous pilot, dowódca Deluvian Reyes Cruz, został zawieszony w przestrzeni przez trzy miesiące. Mając ambitną nadzieję na ustanowienie rekordu odległości pokonanej od Słońca, zamiast tego znalazł się uwięziony w martwej otchłani poza krawędzią Drogi Mlecznej, bez wątpienia ryzykując kosmiczne szaleństwo. Dotarcie do tego punktu zajęło mu ponad miesiąc, a utknął tam od listopada. W tym tygodniu ratunek jest wreszcie w zasięgu wzroku”. F. Brown, An Elite Dangerous pilot has been stuck in space for three months, <https://www.pcgamer.com/an-elite-dangerous-pilot-has-been-stuck-in-space-for-three-months/>, dostęp: 10.12.2020.

[15] Por. R. Kochanowicz, Opisać świat wspomnieniem. Antecendencje w najnowszych fabularyzowanych grach cyfrowych, „Forum Poetyki” 2020, vol. 19, s. $34-47$. 


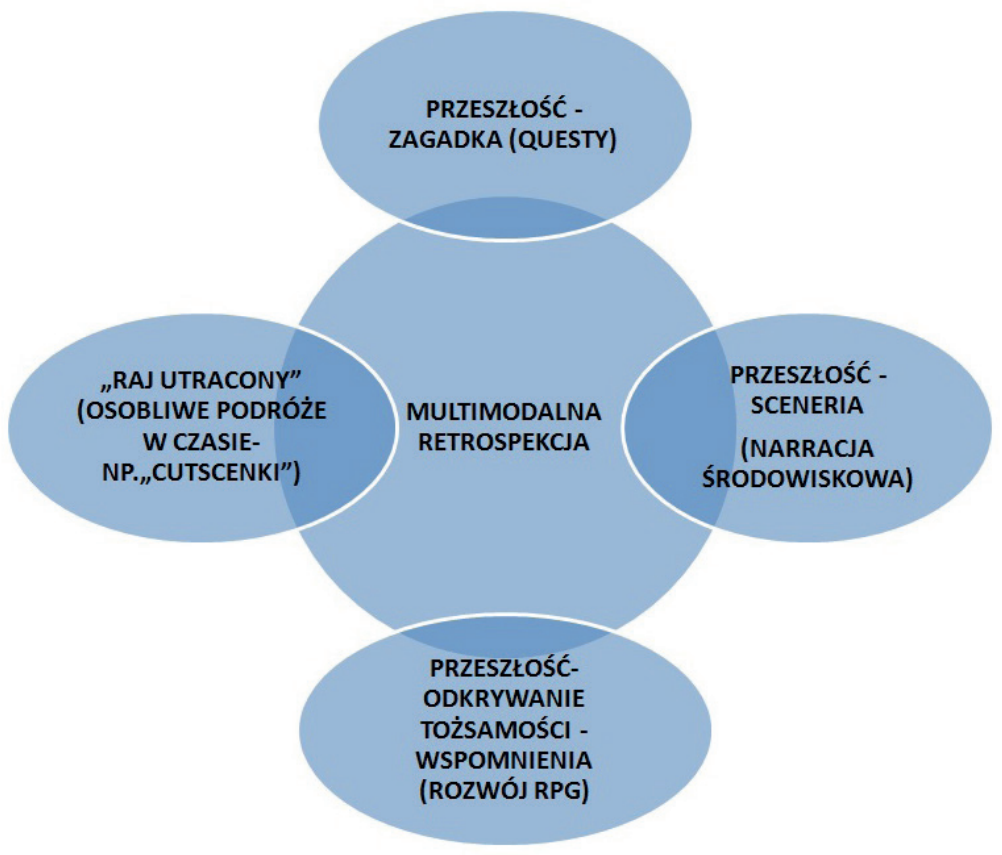

a $\mathrm{z}$ drugiej - z multiplikowania sprawdzonych, narracyjnych rozwiązań. W pierwszym przypadku można mówić o porządkowaniu układu zdarzeń, który będzie zrozumiały dla odbiorcy, czyli o zachowaniu logiki przyczyny i skutku w eksplorowanym - najczęściej fantastycznym - cyfrowym świecie[16]. Z kolei drugi aspekt ma podłoże stricte komercyjne - powiela się rozwiązania, które przyniosły zysk ze sprzedaży wcześniejszych produkcji (widać to szczególnie wyraźnie na przykład w przypadku rozwoju serii gier BioWare, czy seryjnych produkcji Ubisoftu - Assassin 's Creed). W efekcie utrwalił się dość wyraźny schemat sankcjonujący przeszłość jako podstawowy element światotwórczy - tematyczną ramę określającą w warstwie fabularnej rozgrywaną/współtworzoną przez gracza teraźniejszość, której efektem będzie przyszłe, bardziej lub mniej „szczęśliwe” i uzależnione od wcześniejszych decyzji gracza zakończenie:
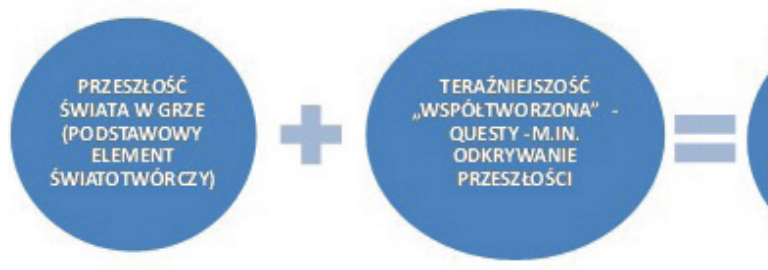

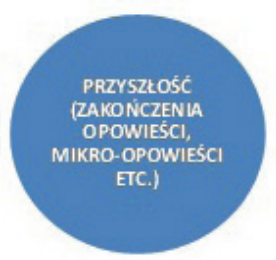

Il. 5. Schemat przeszłośćteraźniejszość-przyszłość. Źródło: opracowanie własne

Il. 4. Retrospekcje w grach. Źródło: opracowanie własne

sobą w faktycznej i potencjalnej relacji przyczynowej stanowią punkt odniesienia dla działań protagonisty. Mechanizm generowania chronologicznej fabuły
[16] Chodzi tu głównie o „mechanizm generowania chronologicznej fabuły", o którym pisze m.in. Mariusz M. Leś: „Postacie i stany rzeczy pozostające ze 
Dla przykładu - Wiedźmin 3: Dziki Gon rozpoczyna się od retrospektywnego snu, w którym poznajemy kulisy dzieciństwa Ciri i współtworzoną następnie przez gracza - w trakcie rozgrywki - rolę Geralta-rodzica. Rozpoczęta retrospekcją przygoda okaże się ponadto zaprojektowanym w poszczególnych questach, wnikliwym badaniem przeszłości (zarówno losów poszczególnych postaci, jak i minionych zdarzeń). W obu przywołanych wyżej produkcjach Ubisoftu przeszłość - ukazana albo w „cutscenkach”, albo w grywalnych „flashbackach" - odsłania dramatyczny los rodzinny bohatera i uzasadnia, wyznaczając główny wektor rozwoju fabuły, kolejne rozgrywane sytuacje. W Fallout 4 cały ukazany w grze świat pozostaje jednym wielkim rumowiskiem, świadectwem minionej i pełnej błędów „świetności”, a gracz - podobnie, jak w Wiedźminie - eksplorując, rekonstruuje przeszłość. Prawdziwym amalgamatem tematycznych konkretyzacji czasu jest również produkcja Cryptic Studios - Star Tek Online. W tym przypadku temporalną tematykę uzasadniają serialowe pierwowzory. Fantastycznonaukowe, filmowe uniwersum Star Treka zostało jednak przez Cryptic zaadaptowane w dość szczególny sposób. Ujęta w grze opowieść, podzielona na wzór serialowy na tak zwane epizody (Episodes), oprócz własnego porządku fabularnego, zresztą dość luźno potraktowanego, jest też swoistą, swobodną rekapitulacją motywów zaczerpniętych $\mathrm{z}$ większości serialowych odsłon (poczynając od Star Trek: Original Series, Next Generation, poprzez Deep Space Nine, Voyager i Enterprise, a na Star Trek: Discovery kończąc). I w tym sensie staje się poniekąd transmedialną "podróżą sentymetalną" dla miłośników filmowej serii. Odnajdą oni bowiem w grze znajome sylwetki ulubionych bohaterów (jak na przykład widniejącą na poniższej ilustracji wirtualną wersję Michael Burnham z Discovery) i mogą - niejako wraz z nimi - współtworzyć nowy wariant cyfrowej przygody (il. 6).

Wypada też zaznaczyć, że twórcy gry szeroko rozwinęli zapożyczone z filmów motywy związane z czasem i z multiwersum. Współtworzone przez gracza wydarzenia to często podróże do przeszłości, przyszłości czy świata równoległego. Można wprost powiedzieć, że produkcja Cryptic Studios zawiera kumulację tematycznych konkretyzacji czasu - odnajdziemy w niej między innymi niemal wszystkie warianty fantastycznonaukowej temponautyki[17].

Konkretyzacje marketingowe
"Czas to pieniądz" - owo popularne powiedzenie w pełni oddaje charakter marketingowych konkretyzacji czasu w grach cyfrowych. To zjawisko nie pojawia się jednak we wszystkich produkcjach, choć sukcesywnie zaczyna obejmować coraz większy obszar cyfrowej roz- na podstawie narracji przebiega - zdaniem Mieke Bal - zgodnie z prawami «logiki potocznej» (automatycznymi schematami poznawczymi)"; M.M. Leś,
Fantastycznonaukowe podróże w czasie. Między logiką a emocjami, Białystok 2018, s. 194.

[17] Por. ibidem, s. 75-137. 


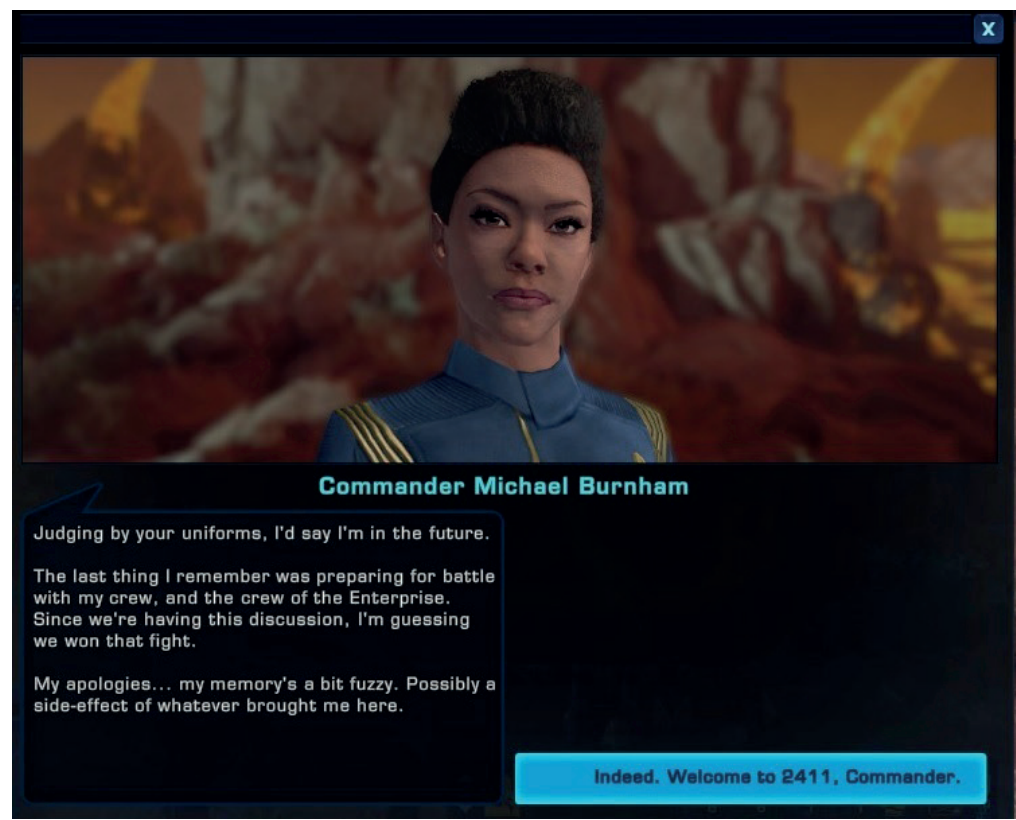

rywki (szczególnie aplikacje przeznaczone na urządzenia mobilne) i ściśle wiąże się z komercyjnymi przemianami gier oraz ich ewolucją. Ciekawostką pozostaje fakt, że można powyższy proces zaobserwować nawet w ramach śledzenia rozwoju pojedynczego tytułu - na przykład uruchomionych ponad dekadę temu gier MMO, jak wspomniane już LOTRO czy STO. Swoista „monetyzacja czasu” i tak zwane in-game advertising jest najczęściej efektem zmiany modelu płatności z subskrypcyjnego na free-to-play (nierzadko też pay-to-win) i wprowadzenia do gry mikrotransakcji. Nie pozostaje to bez wpływu na charakter gameplaya, sposób prowadzenia rozgrywki, rywalizację i w konsekwencji na zmiany niemal całego cyfrowego środowiska. Okazuje się ponadto, że właśnie monetyzacja aspektów temporalnych w grach cyfrowych jest jednym z kluczowych marketingowych zabiegów, który gwarantuje zyski, choć równocześnie w znacznym stopniu modyfikuje i komercjalizuje gameplay. Mechanika gry nie ma już bowiem graczowi dostarczać tylko satysfakcji, ale stwarzać problemy i przeszkody, które najłatwiej zniwelować, płacąc za ich likwidację. Takim problemem i przeszkodą bardzo często jest czas. Widać to wyraźnie w LOTRO, gdzie twórcy sukcesywnie konkretyzują go marketingowo, wprowadzając do świata gry płatne rozwiązania - wpływające na wrażenie upływu czasu i ułatwiające prowadzenie rozgrywki. Tytuł został uruchomiony w 2007 roku i początkowo funkcjonował w ramach modelu sybskrypcyjnego. Zaprojektowany w grze gameplay nie był pierwotnie dostosowany do mikrotransakcji. Zmiany zapoczątkowało w 2010 roku przejście na model F2P i wprowadzenie płatności in-game. Wówczas też zaczęto funkcjonalizować poszczególne elementy mechaniki gry
Il. 6. Zrzut ekranu z gry Star Trek Online, Cryptic Studios, 2010. Źródło: opracowanie własne 
pod kątem marketingowym. Wprowadzono dodatkowy i dość skomplikowany system tzw. in-game currency (turbine points, później lotro points, mithril coins itp.), który umożliwił graczom finansowe rozwiązywanie gameplyowych problemów. Rozwój prowadzonej postaci zakładał pierwotnie wykonanie szeregu czynności, które - choć miały swój urok - były dość czasochłonne. Statystyki bohatera (umiejętności bojowe, wytrzymałość etc.), decydujące o efektywności jego wpływu na poszczególne elementy cyfrowego środowiska, gracz mógł podnosić, eliminując na przykład setki wilków, niedźwiedzi, orków, goblinów czy innych stworzeń z tolkienowskiego bestiariusza. Wymagało to czasu i cierpliwości, bowiem nie tylko sama liczba stworzeń była problemem, ale także ich respawn time - oczekiwanie, kiedy znowu pojawią się w danej lokacji. Dziś już jednak gracz może albo kupić tak zwany Slayer Deed Boost - czas trwania na przykład 90 minut - który zmniejszy liczbę stworzeń do pokonania, albo po prostu od razu - ale już za wyższą cenę - nabyć określone statystyki. Innym temporalnym problemem, również w LOTRO zmonetyzowanym, jest czas, który gracz poświęcał na doprowadzenie bohatera do określonego, często trudno dostępnego miejsca - zwykle ukrytej w malowniczej kniei postaci NPC. W wersji pierwotniej taka podróż trwała długo, miała często eksploracyjny wymiar, wiązała się z odkrywaniem tajemnic cyfrowego Śródziemia, z poznawaniem okolicy i specyfiki nowej krainy. Dzisiaj gracz, jeśli wcześniej kupi mithril coins, może niejako w mgnieniu oka dotrzeć do celu, ale detali cyfrowego środowiska przy tej okazji już nie pozna. Z analogiczną sytuacją stykamy się w przypadku STO. W tym tytule konkretyzacje marketingowe czasu są jeszcze bardziej związane z gameplayem, system rozwoju postaci oraz statku został bowiem uwarunkowany ukończeniem całej serii osobliwych projektów. Proces jest w części zautomatyzowany - gracz zdobywa określone surowce, uruchamia projekt i następnie czeka kilkadziesiąt, a niekiedy kilkaset godzin na rezultat i powiązaną z nim nagrodę. Nie musi jednak czekać, może kupić jedną z walut, a nią opłacić natychmiastowe ukończenie zadania.

Oba wspomniane tytuły, o czym już pisano, funkcjonują w modelu $\mathrm{F}_{2} \mathrm{P}$, ale związane $\mathrm{z}$ upływem czasu elementy gameplaya intencjonalnie kierują graczy w stronę mikrotransakcji. Odbiorcy, którzy z nich nie skorzystają, będą musieli zainwestować w grę znacznie więcej czasu, a niektórych zadań w ogóle nie zrealizują. Powyższe zjawiska, wraz z intensywnie wykorzystywanym przez twórców in-game advertisingiem (promocje, reklamy i informacje na temat nowych korzyści z mikrotransakcji pojawiające się na przykład na tak zwanych loading screenach), stopniowo zamieniają wirtualny świat - chciałoby się powiedzieć - w jeden wielki bazar.

Podobnych przykładów gier, w których stykamy się z marketingowymi konkretyzacjami czasu, można by wymienić jeszcze mnóstwo. Monetyzacja wkroczyła niemal do każdego z najbardziej popularnych cyfrowych uniwersów. Nie oparł się jej nawet postapokaliptyczny świat z serii Fallout. W 2015 roku ukazał się wydany przez Bethesdę tytuł 
Fallout Shelter (F2P), w którym twórcy, wykorzystując sentyment miłośników serii, zaprojektowali gameplay oparty w całości na marketingowej konkretyzacji czasu. Na rezultat każdej ze swoich decyzji, nawet najbardziej banalnej, gracz musi bowiem czekać wiele godzin, chyba że ulegnie perswazji i zainwestuje swoje oszczędności w „Nuka Colę Quantum” (odpowiednik in-game currency) i wykorzysta ją do natychmiastowego osiągnięcia rezultatu - co wymownie ukazują poniższe ilustracje.
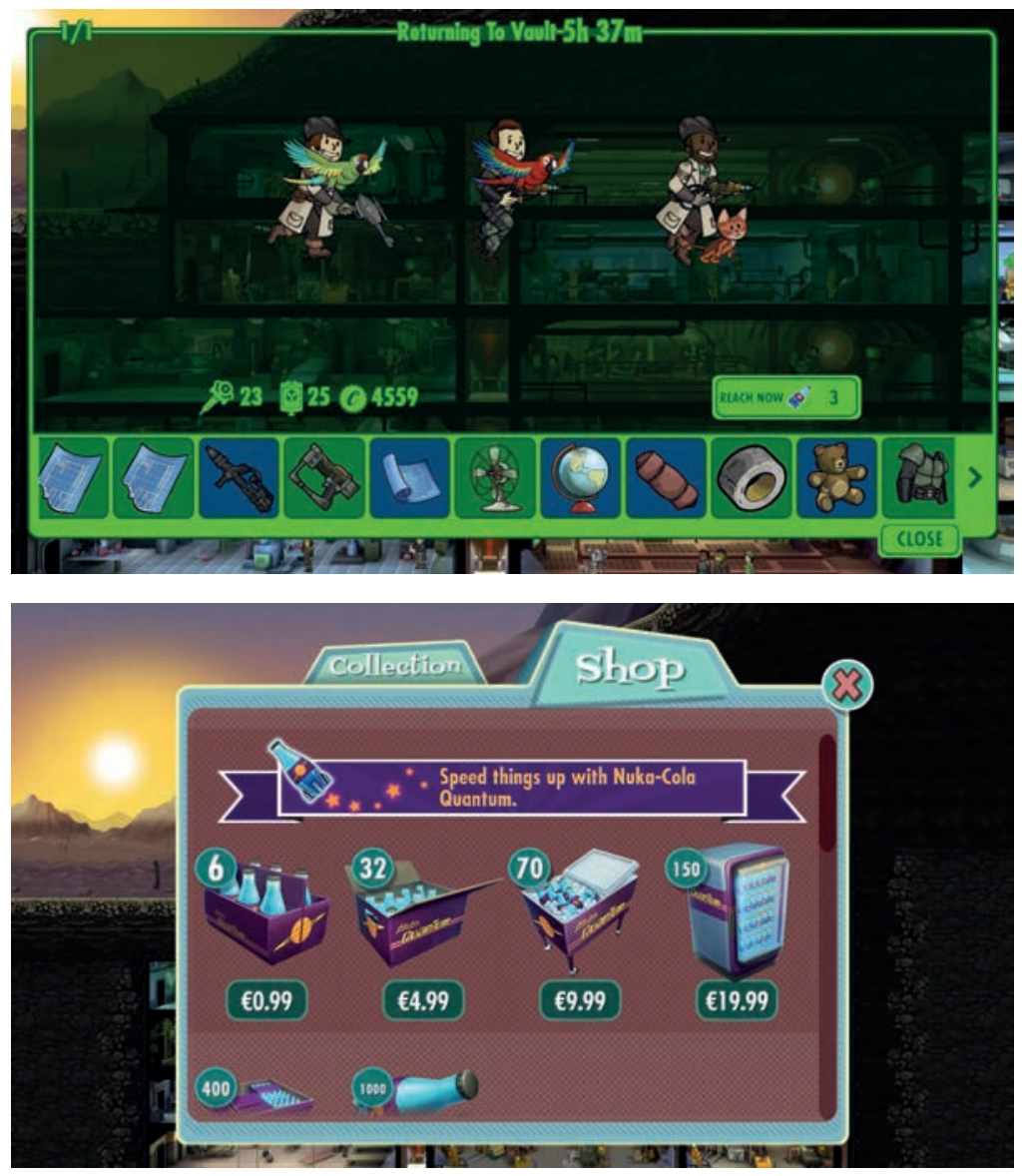

Il. 7, 8. Zrzuty ekranu z gry Fallout Shelter, Bethesda Softworks, 2015. Źródło: opracowanie własne

Omówione wyżej tytuły są świadectwem tego, jak twórcy gier wykorzystują negatywny aspekt czasu. Projektują lub modyfikują gameplay w taki sposób, by temporalne konkretyzacje uwypuklały czasochłonność, uciążliwość oczekiwania czy - ujmując rzecz kolokwialnie po prostu wystawiały cierpliwość odbiorców na próbę. Czas w ten sposób staje się towarem, można przyśpieszyć jego gameplayowy upływ, ale wymaga to zainwestowania realnych środków płatniczych. Z drugiej strony jednak - czas bywa waloryzowany w obszarze gier cyfrowych także pozytywnie. Co więcej, jest często miernikiem decydującym o pozytywnej ocenie tej czy innej produkcji, a określanie atrakcyjności 
nowego tytułu w kategoriach temporalnych na stałe weszło do poetyki branżowych recenzji[18].

Innymi słowy - liczba godzin rozgrywki zaoferowana w cyfrowej produkcji staje się zwiastunem marketingowego sukcesu oraz kuszącą obietnicą intensywnej, długotrwałej i atrakcyjnej rozrywki. Trudno jednak oprzeć się wrażeniu, że mamy tu do czynienia ze swoistym paradoksem. Zachęcająca do zabawy liczba oferowanych godzin gry bywa bowiem w jej trakcie niejako ponownie kupowana przez odbiorców (nie dotyczy to wszakże cyfrowego Wiedźmina), ale już nie w celu przedłużenia, a skrócenia długotrwałych gameplayowych procesów.

Komercjalizacja czasu w obszarze gier cyfrowych wykracza ponadto poza obszar software'u i obejmuje kwestie hardware'owe. Przywołane na początku problemy graczy z pingiem czy lagami znajdują bowiem również swoją zmonetyzowaną konkretyzację. Przykładem pozostają oferty producentów komputerowego sprzętu, którzy reklamują asortyment w kategoriach temporalnych:

Nawiązaliśmy współpracę z wtfast, aby pomóc Ci grać bez opóźnień, opóźnień i utraconych pakietów. Dzięki 6-miesięcznej subskrypcji do prywatnej sieci wtfast Gamers, będziesz cieszyć się niższym pingiem i płynniejszą rozgrywką online. Kup kartę graficzną ASUS - i nie czekaj! [19]

Podsumowanie

Zarysowane wyżej temporalne aspekty gier cyfrowych nie wyczerpują - rzecz jasna - całości zagadnienia, są jedynie - z konieczności - rekonesansem badawczym. Omawiana problematyka wydaje się bowiem jednym z najbardziej skomplikowanych i zarazem najciekawszych zagadnień, które określają specyfikę wspomnianych gier i decydują o ich osobnej pozycji w obszarze tzw. nowych mediów. Cyfrowe, ujęte w poszczególnych tytułach światy w swej dynamice i multimodalnej złożoności skupiają niemal wszystkie reprezentacje zjawisk temporalnych, z którymi stykamy się w literaturze, filmie, muzyce, malarstwie i architekturze. Z kolei sam czas - jak pisze Mariusz M. Leś: „[...] wpisuje się i jest wpisywany w konteksty teorii fizycznych i kosmologicznych, w zależności społeczne, historyczno-społeczne i ekonomiczne, rozważania eschatologiczne, uwarunkowania środowiskowe, psychologiczne, biologiczne i ewolucyjne, wierzenia religijne, egzystencjalne narracje, historiozoficzne, intelektualne i artystyczne konstrukcje"[20].

Wypadałoby zatem w tym miejscu zakończyć rozważania popularnym fragmentem poezji Horacego:

$[\ldots]$

Mknie rok za rokiem, jak jedna godzina.

Więc łap dzień każdy, a nie wierz ni trochę

W złudnej przyszłości obietnice płoche.[21]

[18] Por. J. Mirowski, 90 misji i 30 godzin gry - nowości o dodatku Wiedźmin 3: Krew $i$ wino, <https:// www.gry-online.pl/newsroom/9o-misji-i-3o-godzin-gry-nowosci-o-dodatku-wiedzmin-3-krew-i-wino/ zf17eaa>, dostęp: 10.12.2020
[19] Por. Upgrade to an ASUS graphics card and give your games the VIP treatment, <https://www.asus. com/event/VGA/wtfast/>, dostęp: 10.12.2020.

[20] M.M. Leś, op.cit., s. 25.

[21] Horacy, Wybór poezji, oprac. J. Krókowski, Kraków 1973, s. 21. 
Brown F., An Elite Dangerous pilot has been stuck in space for three months, <https:// www.pcgamer.com/an-elite-dangerous-pilot-has-been-stuck-in-space-for-three-months/>, dostęp: 10.12.2020

EDSM: Elite Dangerous Star Map, <https://www.edsm.net/pl>, dostęp: 10.12.2020

Horacy, Wybór poezji, oprac. J. Krókowski, Kraków 1973

How Long is a Mizura?, <http://forum.egosoft.com/viewtopic.php?t=272328>, dostęp: 10.12.2020

Jak zmniejszyć ping w CS:GO?, <https://esportmania.pl/counter-strike-global-offensive/csgo-jak-zmniejszyc-ping-instrukcja-poradnik-counter-strike/snw5fhy>, dostęp: 10.12.2020

Kłosiński M., Hermeneutyka gier wideo. Interpretacja, immersja, utopia, Warszawa 2018

Kochanowicz R., Fabularyzowane gry komputerowe w przestrzeni humanistycznej. Analizy, interpretacje $i$ wnioski z pogranicza poetyki, aksjologii, dydaktyki literatury, Poznań 2014

Kochanowicz R., Opisać świat wspomnieniem. Antecendencje w najnowszych fabularyzowanych grach cyfrowych, „Forum Poetyki” 2020, nr 19, s. 34-47

Kubiński P., Gry wideo. Zarys poetyki, Kraków 2016

Leś M.M., Fantastycznonaukowe podróże w czasie. Między logika a emocjami, Białystok 2018

Lore: Calendar, <https://en.uesp.net/wiki/Lore:Calendar>, dostęp: 10.12.2020

Maj K.M., Światotwórstwo $w$ fantastyce. Od przedstawienia do zamieszkiwania, Kraków 2019

Mateas M., Zagal J., Time in Video Games: A Survey and Analysis, <https://www. researchgate.net/publication/247740288_Time_in_Video_Games_A_Survey_ and_Analysis>, dostęp: 10.12.2020

Mirowski J., 90 misji i 30 godzin gry - nowości o dodatku Wiedźmin 3: Krew i wino, $<$ https://www.gry-online.pl/newsroom/90-misji-i-30-godzin-gry-nowosci-o-dodatku-wiedzmin-3-krew-i-wino/zf17eaa>, dostęp: 10.12.2020

Safrański R., Czas. Co czyni z nami i co my czynimy z niego, przeł. B. Baran, Warszawa 2017

Stoff A., Studia z teorii literatury i poetyki historycznej, Lublin 1997

Time of day, <https://lotro-wiki.com/index.php/Time_of_day>, dostęp: 10.12.2020

Upgrade to an ASUS graphics card and give your games the VIP treatment, <https:// www.asus.com/event/VGA/wtfast/>, dostęp: 10.12.2020

Wei H., Bizzocchi J., Calvert T., Time and Space in Digital Game Storytelling, <https://www.hindawi.com/journals/ijcgt/2010/897217/>, dostęp: 10.12.2020 